\title{
DeVeloping a Conceptual Model of Implementation of BUSINESS FUNCTIONS INTEGRATION IN THE INTERNAL Business Process Performance
}

\author{
Department of Informatics Engineering \\ Langlangbuana University \\ Indonesia \\ rwinyulianto@yahoo.com
}

Erwin Yulianto*

Iman Sudirman

Doctoral Program in Management Science

Pasundan University

Indonesia

imansudirman@unpas.ac.id

\section{Sutarman}

Doctoral Program in Management Science Pasundan University

Indonesia

sutarmanelank4@gmail.com

Awan Setiawan

Department of Informatics Engineering

Langlangbuana University

Indonesia

awans2425@gmail.com

Ruhanda

Vice Chancellor of Langlangbuana University

Langlangbuana University

Indonesia

askaraya07@gmail.com

*Corresponding Author email: rwinyulianto@yahoo.com

Peer-review under responsibility of 5th ASIA International Multidisciplinary Conference 2027 (Online) Scientific Committee

http://connectingasia.org/scientific-committee/

(C) 2027 Published by Readers Insight Publisher,

Office \# 6, First Floor, A \& K Plaza, Near D Watson, F-70 Markaz, Islamabad. Pakistan,

editor@readersinsight.net

This is an open access article under the CC BY license (http://creativecommons.org/licenses/by/4.0/). 


\section{A B S T R A C T}

The research used in assessing the performance of internal business processes in this study uses strategic management theory and operations management through the Resource-Based View approach, Market-Based View aspects and Organization Culture. The Banking Industry has to think about the business processes and workflows to empower employees and what they need to do to stay competitive in the face of rapidly changing competition. The method used in this research is a Literature Review with a descriptive approach that will produce a conceptual model. The resulting conceptual model development was adopted from DeLone and McLean's Model about the success of the Information System which was combined with the input variables studied to produce an implementation model for the integration of business functions to improve the performance of internal business processes.

Keywords: Business Function Integration, Business Process Performance, Market Based View, Resource Based View, Corporate Culture, DeLone and McLean's Model

\section{R E S E A R C H H I G H L I G H T S}

The use of the internet to access services in the economic sector, particularly banking, is still relatively low, only at $7.39 \%$. The low level of internet use to access banking services is basically related to the low level of Indonesian people's access to formal financial institutions, which only reaches $49 \%$ of the total population. (Demirgüç-Kunt, A., Klapper, 2013). The low level of banking access is caused by the low level of public income, complicated bureaucratic bank operations, low financial and banking literacy education, high bank administration costs and the distance between where they live and the location of the bank.

Research on performance in the banking industry, especially in the fields of strategic management and operations management, has been widely studied before. This is in line with the empirical phenomenon that occurs in the fluctuating and unstable performance of national banking. (OJK, 2020)

The continuous development of systems, information and communication technology has profound implications for the integration of business functions such as sales and marketing, procurement, finance and accounting, research and development. The implementation of effective risk management as an inseparable part of organizational processes is an important element in realizing good corporate governance because of the role of risk management in providing reasonable assurance for the achievement of the objectives of the success of activities. (Bach, 2014) 


\section{G R A H I CA L A B S T R A T}

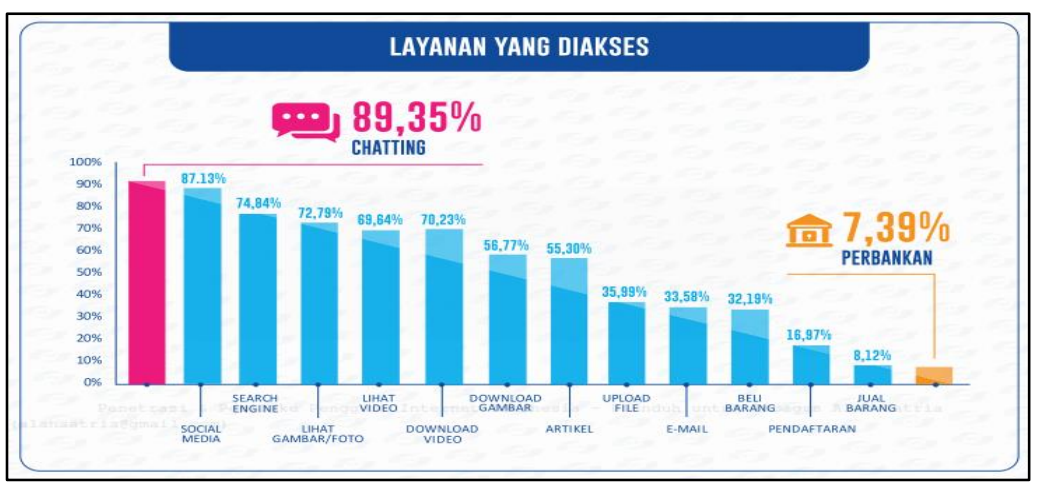

(APJII, 2019)
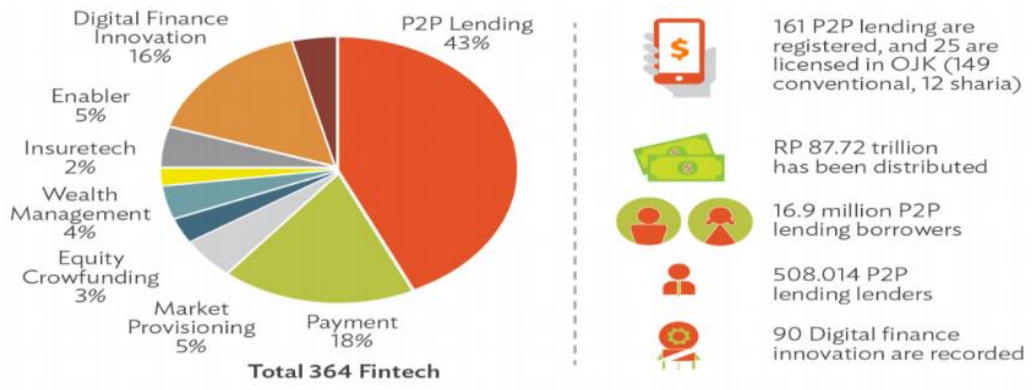

(OJK, 2020)

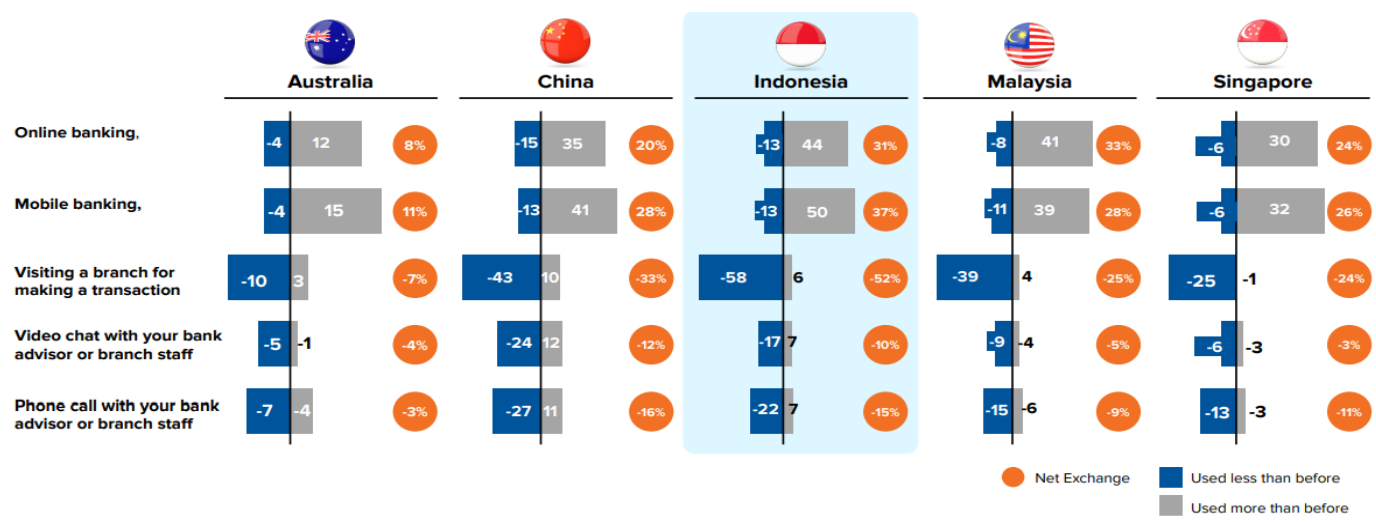

(Utoyo, 2020)

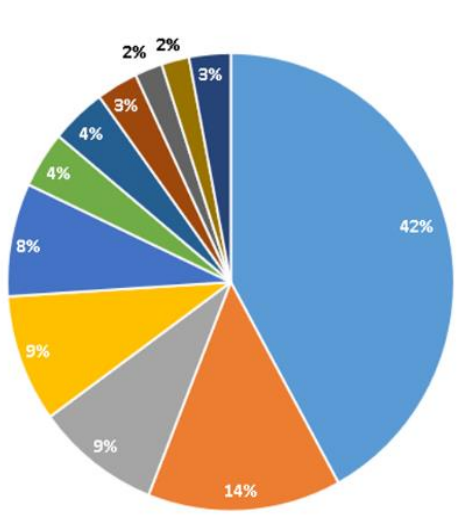

\footnotetext{
= Mobile Technology (42\%)

= Cash Recycling (14\%)

- Interchange Cost Reduction (9\%)

= Government Regulator (9\%)

= PIN Protection (8\%)

= Surcharge Cost (4\%)

- Software Self Service (4\%)

- Vendor Alliance (3\%)

- Virtual Private Network (2\%)

= OS Based ATM (2\%)

= Others (3\%)
}

(Fryrear, Alan., Harper, 2012) 

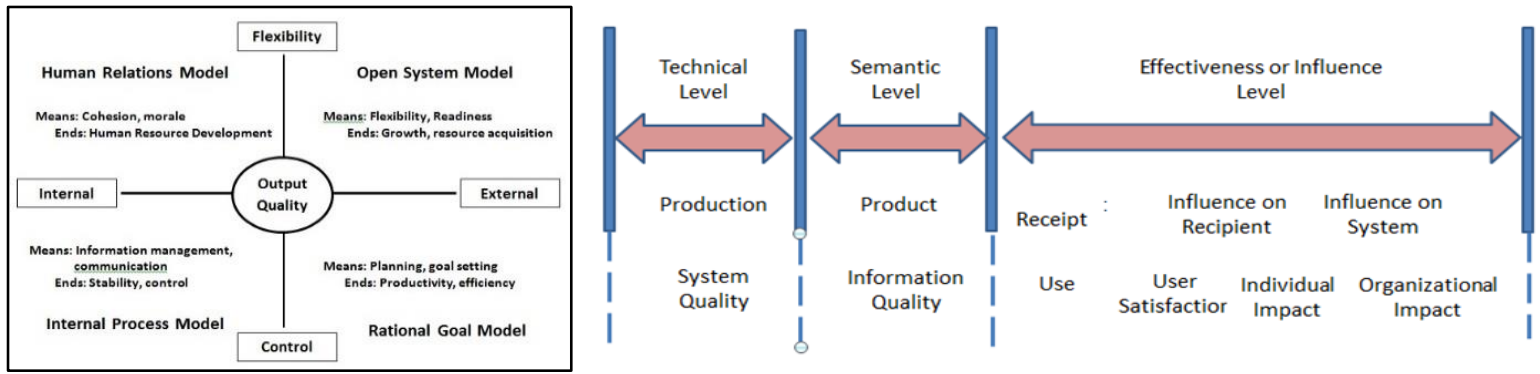

(DeLone, W. H., McLean, 1992)

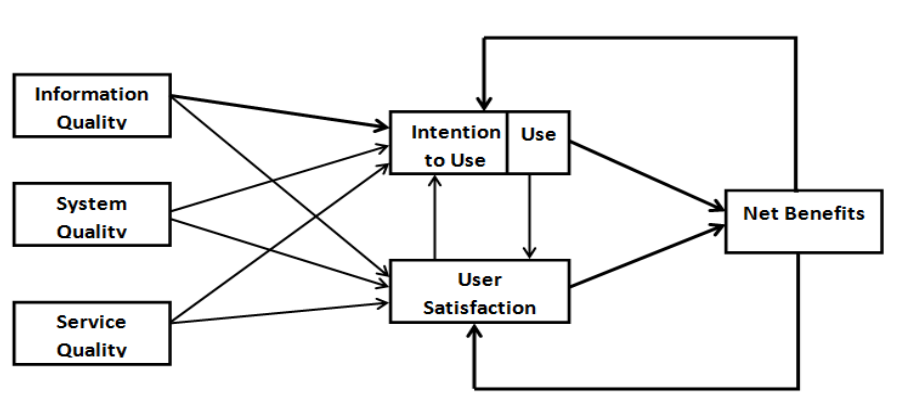

(DeLone, W. H., McLean, 2003)

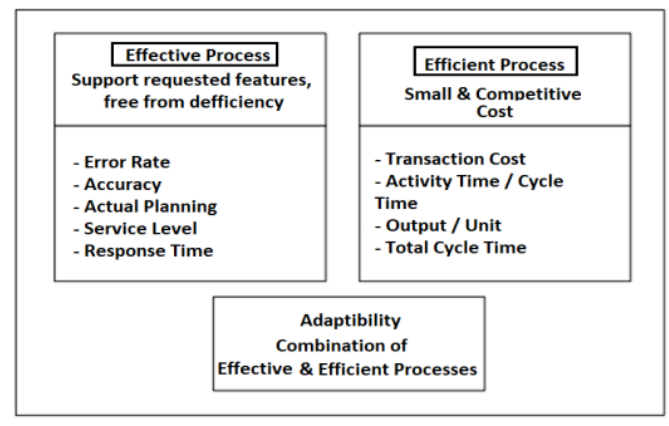

(Frank, Gryna, 2001)

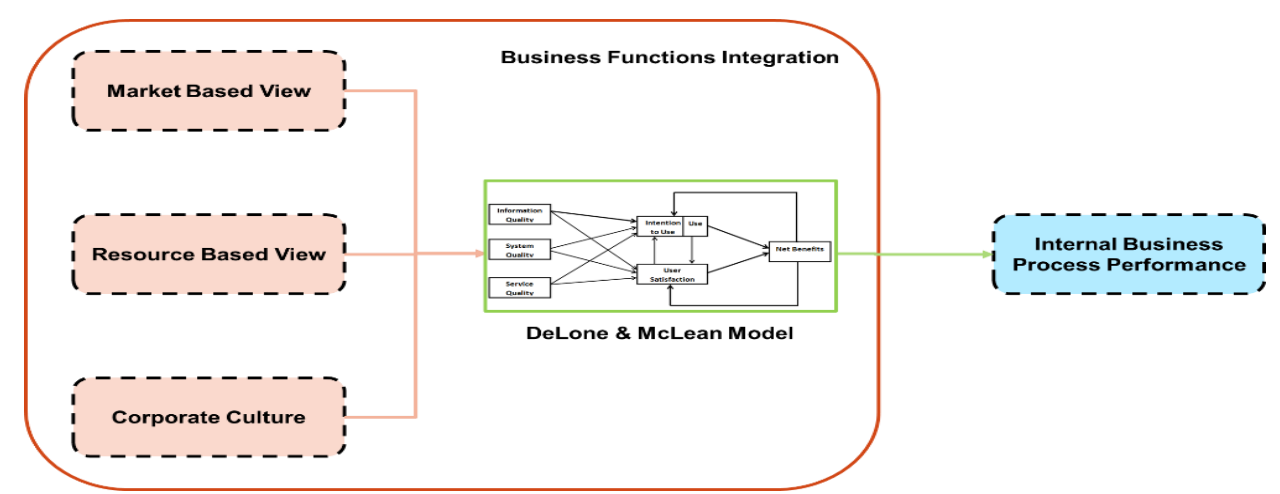

(Research Result, 2021)

\section{Research Objectives}

Propositions of this research raised in modeling include:

1. Identify the system integration business functions.

2. The dominant variables involved in the system integration of business functions.

3. Development of a conceptual model for the implementation of an effective integration system for business functions so as to improve the performance of internal business processes.

\section{Methodology}

The research method used is the Literature Review method. The Literature Review method is a research conducted by researchers by collecting a number of books, journals, papers 
and magazines related to research problems and objectives. The literature review research method was chosen to reveal various theories that are relevant to the problem in the case study being faced / studied as a reference in the discussion and discussion of the research results.

\section{Results}

Based on Bank Indonesia, the average annual growth in volume of non-cash transactions for the 2014-2018 period was dominated by Electronic Money of 94.7\%. when compared with the growth of debit cards of $18.6 \%$ and credit cards of $7.1 \%$. Server-based e-money service features extend to the use of Quick Response Code (QR Code). Users only need to scan this code via their smartphone when making transactions using Mobile Banking. Data from the four main banks in Indonesia shows a growth of around 51\% while Internet Banking users have also grown at a growth rate of around $36 \%$. The banking industry around the world, including in Indonesia, will shift towards a more digital, more personal and less physical direction. Structural changes that have taken place in the Indonesian banking sector have increased competition between banks, so that banks in their operations are faced with optimal operational efficiency, so that high market share can be achieved and minimize risk and obtain satisfactory financial performance. Changes are needed so that the banking industry can survive the perfect storm, both in terms of business models, customer behavior, culture and human resources.

\section{Findings}

The conceptual model development for the implementation of the Integration of Business Functions was adopted from the DeLone and McLean Model of the success of Information Systems. The development of the reference model is carried out based on research models that have been carried out into the Market Based View, Resource Based View and Company Culture variables to be able to implement an effective integration of business functions so as to improve the performance of internal business processes

\section{Acknowledgement}

This research was conducted independently at one of the national banks in Indonesia. Thank you to Mr. Promoter and Co Promoter

\section{References}

APJII. (2019). Penetrasi \& Profil Perilaku Pengguna Internet di Indonesia Survey 2018, Polling Indonesia.

Bach, A. S. (2014). Technological Factors to Improve Performance of Marketing Strategy. ASEE 2014, Zone I Conference.

DeLone, W. H., McLean, E. R. (1992). Information Systems Success: The Quest for the Dependent Variable. Information Systems Research, 60-95. 
DeLone, W. H., McLean, E. R. (2003). The DeLone \& McLean Model of Information System Success: A Ten-Year Update. Journal of MIS.

Demirgüç-Kunt, A., Klapper, L. (2013). Measuring Financial Inclusion: Explaining Variation in Use of Financial Services Across \& Within Countries. Brookings Papers on Economic Activity, 2(11), 1-62.

Frank, Gryna, M. (2001). Quality Planning \& Analysis: From Product Development Through Use. McGraw Hill.

Fryrear, Alan., Harper, T. (2012). ATM Future Trends Report.

OJK. (2020). Laporan Publikasi Bank Umum Konvensional. https://cfs.ojk.go.id/cfs

Utoyo, I. (2020). Banks \& the New Normal: Surfing the Wave of Crisis to Win the Future.

\section{Author's Biography}

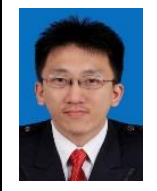

Erwin Yulianto is a lecturer at the Informatics Study Program at Langlangbuana University and is also active as a consultant and project manager in the fields of Information Technology, HRM, Risk Management, Finance and Business. Currently the author is pursuing a doctoral education at Pasundan University with a concentration in Operations Management.

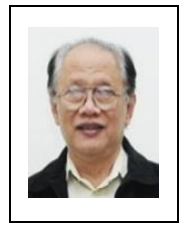

Prof. Dr. Ir. Iman Sudirman, DEA is an active lecturer at Pasundan University and the Bandung Institute of Technology. He has served as Unpas Rector for the period 1995 - 2003. Currently he is the promoter of the first author at Pasundan University

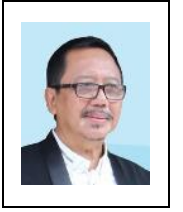

Prof. Dr. Ir. H. Sutarman, M.Sc. is an active lecturer at Pasundan University. He has served as Chancellor of Majalengka University for the 2014-2018 period. He is currently the co-promoter of the first author at Pasundan University

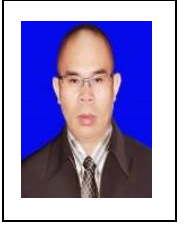

Awan Setiawan is a lecturer at the Informatics Study Program at several universities in Bandung. Besides teaching, the author is also active as an IT consultant, and as an instructor for security awareness certification, and as an instructor in other IT fields. Currently the author is completing a Dissertation on Information Systems Studies.

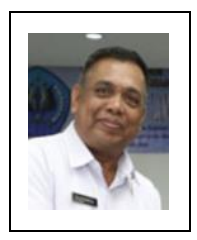

Ruhanda serves as Vice Rector II at Langlangbuana University Bandung. Currently the author is completing a dissertation with a concentration in Human Resource Management 